\title{
Effects of Dietary Chitosan and Neem Leaf Meal Supplementation on Intestinal Bacterial Count in Broiler Chickens
}

\author{
S.D. Sirsat ${ }^{1^{*}}$, P. Visha $^{2}$ and K. Nanjappan ${ }^{2}$ \\ ${ }^{1}$ Department of Veterinary Physiology, Bombay Veterinary College, Mumbai, India \\ ${ }^{2}$ Department of Veterinary Physiology, Veterinary College and Research Institute, \\ Namakkal, India \\ *Corresponding author
}

\section{A B S T R A C T}

Keywords

Neem leaf, Meal supplementation, Bacterial count

Article Info

Accepted:

26 December 2017

Available Online:

10 January 2018
A study was conducted to determine the effects of dietary supplementation with chitosan, neem leaf meal and their combination at different levels in broiler on intestinal bacterial count and total Coliform and Clostridium count).Two hundred forty broilers (Vencobb) were randomly assigned to eight groups with three replicates of ten birds each and were fed for six weeks and slaughtered. Supplementation of antibiotic, chitosan, NLM and chitosan NLM combination caused a significant reduction in the total gut bacterial counts and total Clostridial and Coliform counts of broiler chickens. The birds supplemented with chitosan at $0.025 \%$ and $0.05 \%$ alone or in combination with NLM at $0.025 \%$ chitosan and $0.5 \%$ neem leaf meal and $0.05 \%$ chitosan and $1.0 \%$ neem leaf meal both the levels resulted in significant $(\mathrm{p}<0.05)$ reduction in intestinal bacterial count and total Coliform and Clostridium count in comparison to all other treatment and control groups.

\section{Introduction}

Chitosan is a biocompatible polymer derived by deacetylation of chitin from shellfish, and its use in industry, agriculture, food science, pharmaceuticals and biomedical fields is well described (Rabea et al., 2003; Senel and McClure, 2004; Yin et al., 2009; Friedman and Juneja, 2010). The interest in chitosan as a biological sanitizer arises from several studies reporting its antimicrobial and anti-oxidative effects in foods (No et al., 2002; Friedman and Juneja, 2010). The antimicrobial activities of chitosan against Food borne pathogens have been extensively investigated in the food industry (Singla and Chawla, 2001; No et al., 2002; Senel and McClure, 2004; Petrovich et al., 2008; El Hadrami et al., 2010; Kong et al., 2010; Vargas and Gonzalez-Martinez, 2010).

Azadirachta indica, commonly known as neem, has attracted worldwide attention in recent years, owing to its wide range of medicinal properties. Neem is a tropical evergreen tree native to Indian sub-continent. Neem possesses limonoids, proto-limonoids, 
tetranortri-terpenoids, pentanortri-terpenoids, hexanortri-terpenoids, and some non-terpenoid (Koul et al., 2006). Most of the plant parts such as fruits, seeds, leaves, bark, and roots contain compounds with proven antiseptic, antiviral, antipyretic, anti-inflammatory, antiulcer, and antifungal properties (Brahmachari, 2004). Neem leaves exhibit immune-modulatory, anti-inflammatory, antihyperglycaemic, antiulcer, antimalarial, antifungal, antibacterial, antiviral, antioxidant, anti-mutagenic and anti-carcinogenic properties (Tiwari et al., 2014). Also chitosan has synergetic effect with Neem leaf meal owing to these properties, neem leaf meal has been tried as a feed additive in animals.

Thus present experiment was conducted to determine the effect of dietary chitosan and neem leaf meal and their combinations at different level on fat deposition and digestive enzyme activities in broiler chickens

\section{Materials and Methods}

Two hundred and forty numbers (240) of dayold broiler chicks (Vencobb 400) were wing banded, weighed and randomly distributed to eight groups with three replicates of ten chicks each based on the body weight to namely $\mathrm{T} 1$, T2, T3, T4, T5, T6, T7 and T8.

The experiment was undertaken in the Department of Veterinary Physiology, Veterinary College and Research Institute, Namakkal (Tamilnadu). All the chicks were reared up to 42 days in cage system under standard managemental practices with ad. lib. feed and water supply. The experimental diets were formulated according to the standards prescribed in Bureau of Indian Standards (BIS, 1992) and fed to the birds as per the following schedule. At the end of the experiment $\left(42^{\text {nd }}\right.$ day), six birds per treatment group were randomly selected and slaughtered by halal method. The intestinal contents were collected in separate sterile vials for the estimation intestinal enzyme activities. The abdominal fat was collected and weighed. The eight treatment groups are as follows:

Group T1: Basal diet without antibiotic

Group T2: Basal diet with $50 \quad \mathrm{mg}$ Oxytetracycline/kg

Group T3: Basal diet without antibiotic + $0.025 \%$ chitosan

Group T4: Basal diet without antibiotic + $0.05 \%$ chitosan

Group T5: Basal diet without antibiotic + $0.5 \%$ neem leaf meal

Group T6: Basal diet without antibiotic + $1.0 \%$ neem leaf meal

Group T7: Basal diet without antibiotic + $0.025 \%$ chitosan and $0.5 \%$ neem leaf meal

Group T8: Basal diet without antibiotic + $0.05 \%$ chitosan and $1.0 \%$ neem leaf meal

\section{Estimation of intestinal bacterial count}

The microbial count was done as per the method of Smits et al., (1998). Briefly, immediately after slaughter, one gram of intestinal content was transferred to sterile tube and diluted with $9 \mathrm{ml}$ of sterile normal saline. All the samples were subjected to six serial dilutions.

One $\mathrm{ml}$ of the last dilution was inoculated into sterile Mac Conkey agar, Perfringens agar, MRS agar plates for isolation and enumeration of Escherichia coli, Clostridium spp and Lactobacillus spp respectively. The agar plates were incubated for $36 \mathrm{~h}$ and the colonies were counted. The result was expressed as $\log _{10}$ colony forming unit/ gram of digesta. 


\section{Statistical analysis}

The data collected were analysed using SPSS ${ }^{\circledR} \quad 20.0$ software package. The completely randomized design method was followed for the experiment (Snedecor and Cochran, 2007) and the data collected were analysed using SPSS ${ }^{\circledR} 20.0$ software package. Post-hoc analysis was done by Tukey honestly significance difference test.

\section{Results and Discussion}

The effect of supplementation of chitosan, neem leaf meal and their combination on the intestinal bacterial count in broiler chickens is presented in Table 1, Plate 1, Plate 2 and Plate 3.

The mean total intestinal bacterial count $\left(\log _{10}\right.$ $\mathrm{cfu} / \mathrm{g}$ ) in broiler chickens were 5.37, 5.88, $5.23,5.81,5.07,4.15$ and 4.12 in the treatment groups $T_{2}$ to $T_{8}$ as compared with 6.58 in the control group of broiler chickens.

The mean total intestinal bacterial count was significantly $(\mathrm{p}<0.05)$ higher in the control group, $T_{3}$ and $T_{5}$ as compared with $T_{7}$ and $T_{8}$ groups of broiler chickens. The mean total intestinal bacterial count was significantly $(\mathrm{p}<0.05)$ lowest in the $\mathrm{T}_{7}$ and $\mathrm{T}_{8}$ groups of broiler chickens.

The mean total Coliform count $\left(\log _{10} \mathrm{cfu} / \mathrm{g}\right)$ in broiler chickens were 4.30, 4.59, 4.34, 4.32, $3.79,3.58$ and 3.28 in the treatment groups $T_{2}$ to $\mathrm{T}_{8}$ as compared with 4.86 in the control group of broiler chickens. The mean total Coliform count was significantly $(\mathrm{p}<0.05)$ higher in the control group as compared with $\mathrm{T}_{7}$ and $\mathrm{T}_{8}$ treatment groups. The $\mathrm{T}_{8}$ group of broiler chicken had a significantly $(\mathrm{p}<0.05)$ lowest mean total Coliform count. The treatment groups $T_{2}, T_{4}, T_{5}$ and $T_{6}$ did not differ significantly $(\mathrm{p}<0.05)$ in their mean Coliform count.

The mean total Clostridial count $\left(\log _{10} \mathrm{cfu} / \mathrm{g}\right)$ in broiler chickens were 2.68, 2.82, 2.20, 2.39, $1.92,1.65$ and 1.39 in the treatment groups $\mathrm{T}_{2}$ to $\mathrm{T}_{8}$ as compared with 3.34 in the control group of broiler chickens. The mean total Clostridial count was significantly $(\mathrm{p}<0.05)$ higher in the control group as compared with $\mathrm{T}_{4}, \mathrm{~T}_{6}, \mathrm{~T}_{7}$ and $\mathrm{T}_{8}$ treatment groups. The $\mathrm{T}_{7}$ and $\mathrm{T}_{8}$ groups of broiler chickens had significantly $(\mathrm{p}<0.05)$ lowest mean total Clostridial count. The treatment groups $T_{2}, T_{3}, T_{4}, T_{5}$ and $T_{6}$ did not differ significantly $(\mathrm{p}<0.05)$ in their mean Clostridial count.

\section{Plate.1 Intestinal total bacterial count in broilers}

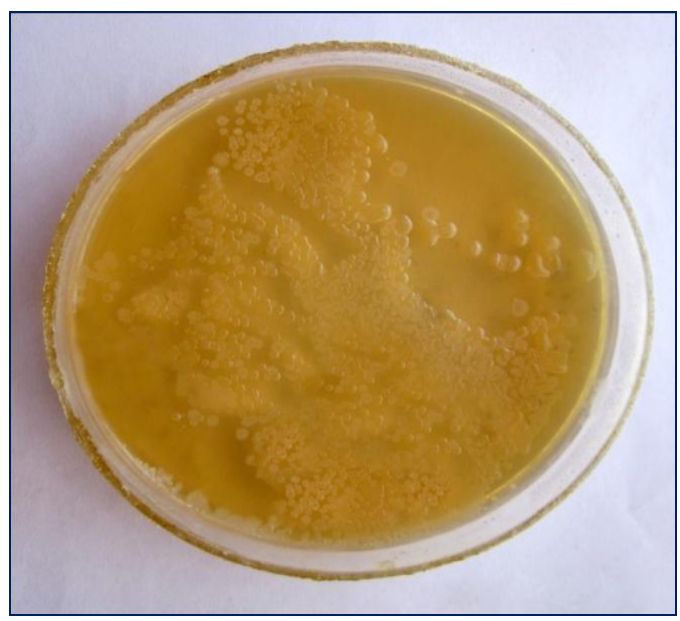

Control

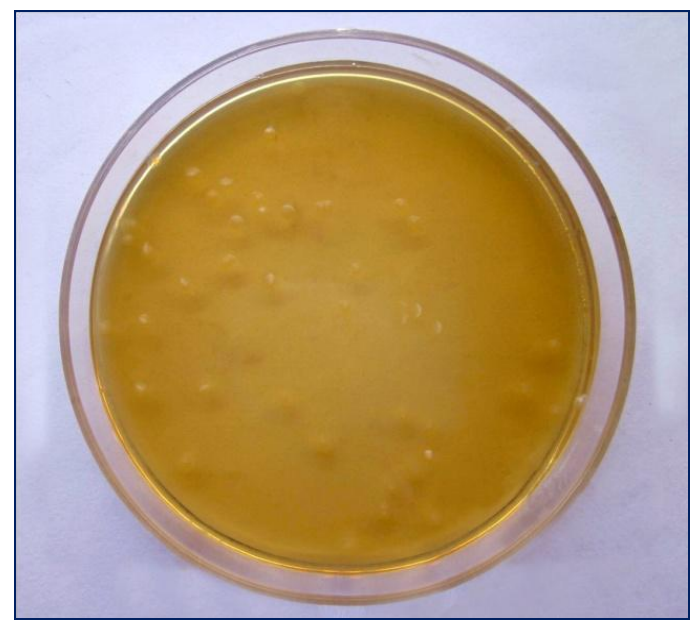

$0.05 \%$ Chitosan and 1\% NLM Group 
Plate.2 Intestinal Escherichia coli Count in broiler chickens

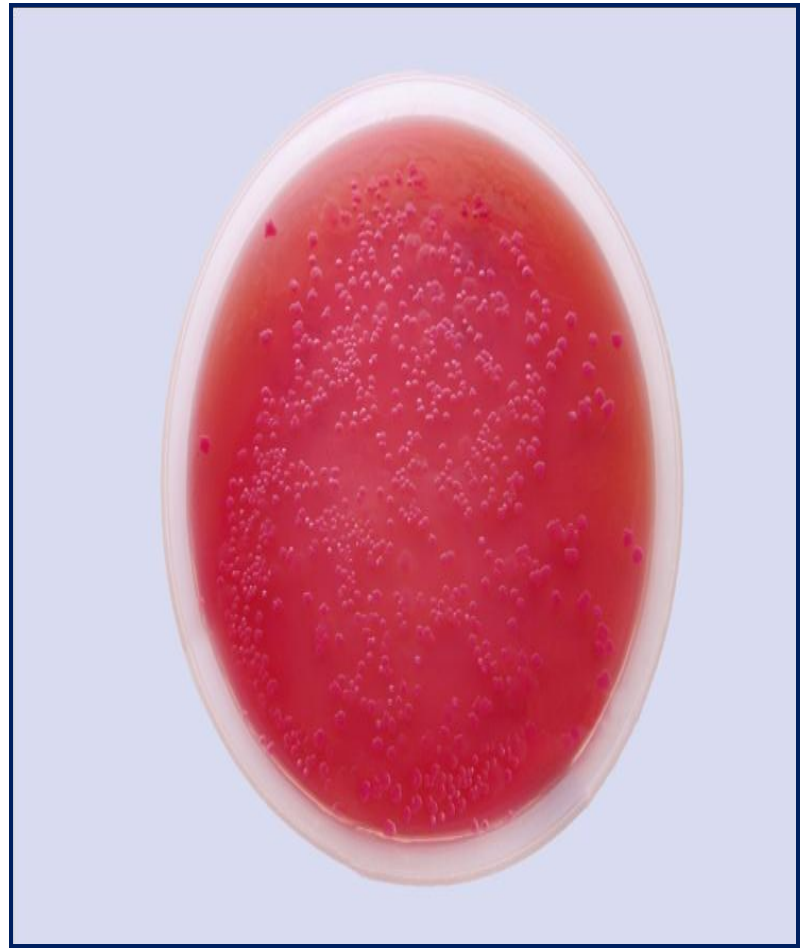

Control

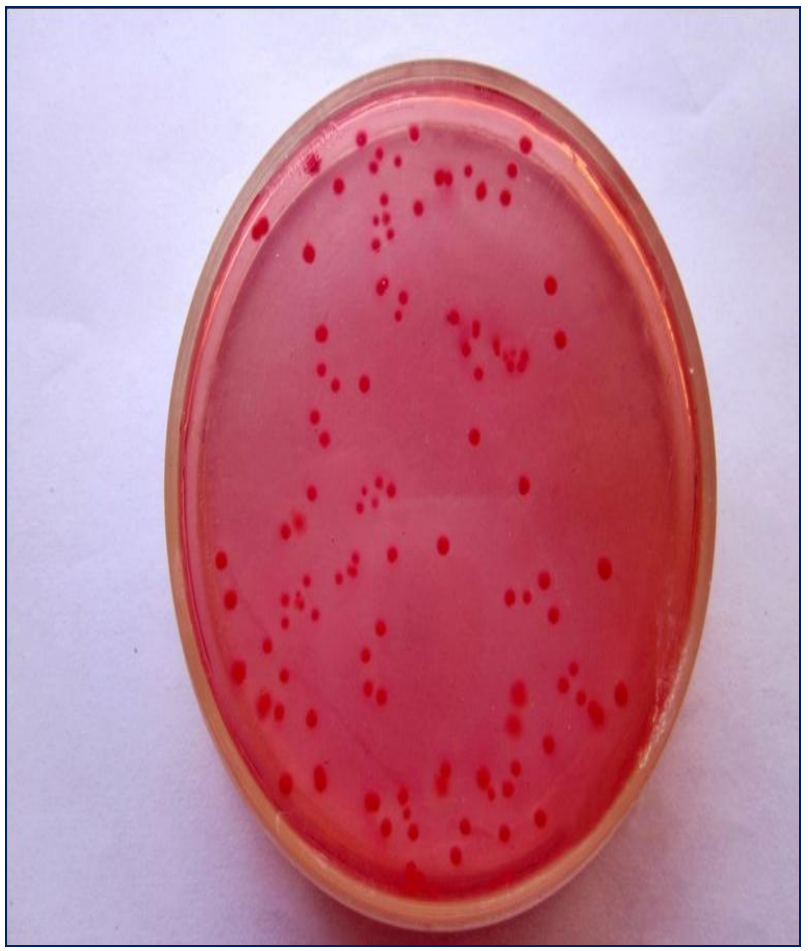

0.05\% Chitosan and 1\% NLM Group

Plate.3 Intestinal Clostridium Count in broiler chickens

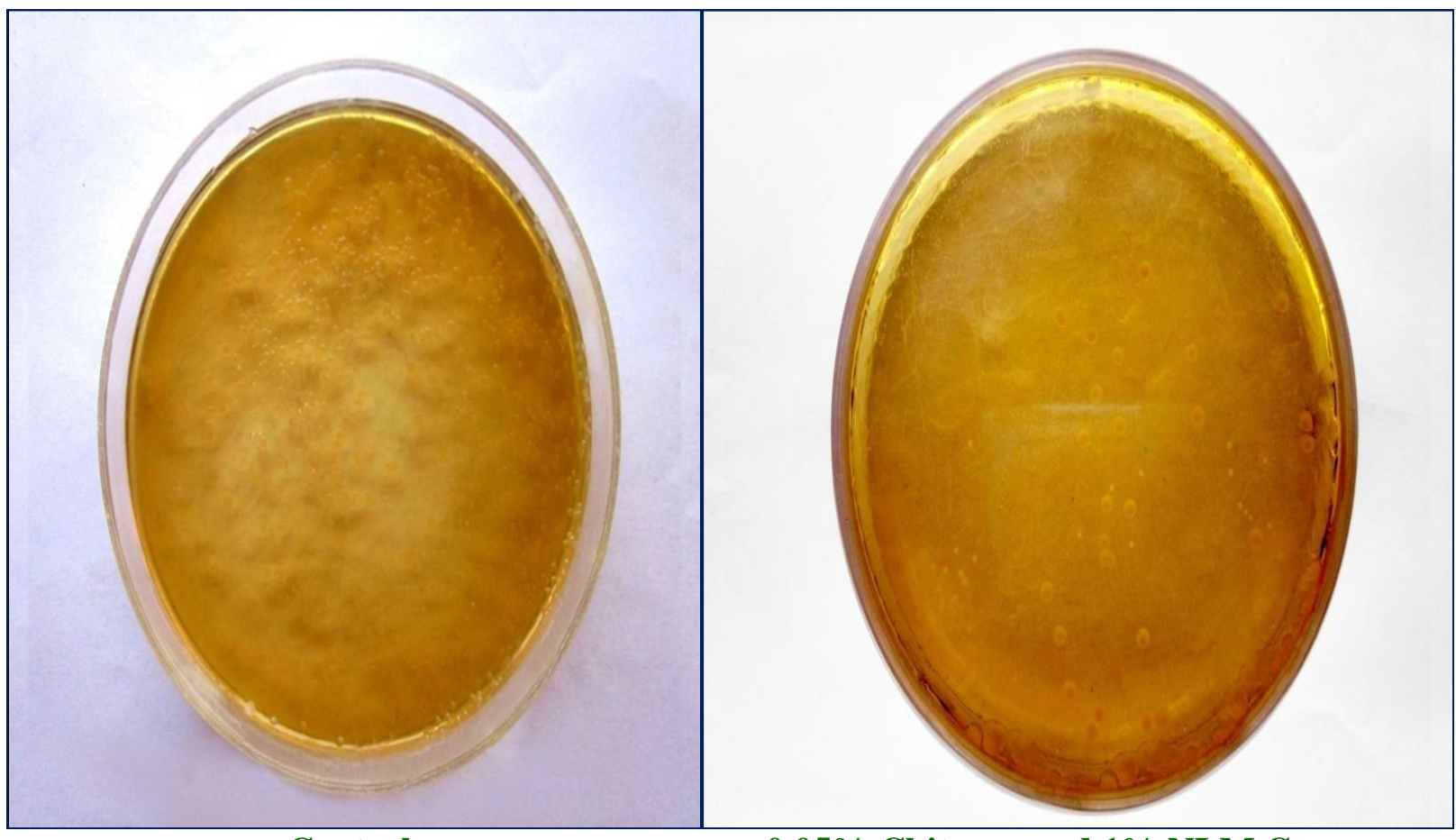

Control

$\mathbf{0 . 0 5 \%}$ Chitosan and 1\% NLM Group 
Table.1 Mean ( \pm S.E.) intestinal microbial count $\left(\log _{10} \mathrm{cfu} / \mathrm{g}\right)$ of broiler chickens as influenced by dietary inclusion of chitosan and neem leaf meal at $6^{\text {th }}$ week of age

\begin{tabular}{|l|c|c|c|}
\hline \multicolumn{1}{|c|}{ Treatment groups } & Total bacterial count & Coliform count & Clostridium count \\
\hline $\begin{array}{l}\mathrm{T}_{1}-\text { Basal diet } \\
\text { (without antibiotic) }\end{array}$ & $6.58^{\mathrm{b}} \pm 0.04$ & $4.86^{\mathrm{c}} \pm 0.05$ & $3.34^{\mathrm{c}} \pm 0.03$ \\
\hline $\begin{array}{l}\mathrm{T}_{2}-\text { Basal diet }+50 \mathrm{mg} \\
\text { Oxytetracycline/kg }\end{array}$ & $5.37^{\mathrm{ab}} \pm 0.02$ & $4.30^{\mathrm{abc}} \pm 0.04$ & $2.68^{\mathrm{bc}} \pm 0.02$ \\
\hline $\begin{array}{l}\mathrm{T}_{3}-\text { Basal diet }+0.025 \% \\
\text { Chitosan }\end{array}$ & $5.88^{\mathrm{b}} \pm 0.02$ & $4.59^{\mathrm{bc}} \pm 0.02$ & $2.82^{\mathrm{bc}} \pm 0.03$ \\
\hline $\begin{array}{l}\mathrm{T}_{4}-\text { Basal diet }+0.05 \% \\
\text { Chitosan }\end{array}$ & $5.23^{\mathrm{ab}} \pm 0.03$ & $4.34^{\mathrm{abc}} \pm 0.04$ & $2.20^{\mathrm{ab}} \pm 0.03$ \\
\hline $\begin{array}{l}\mathrm{T}_{5}-\text { Basal diet }+0.5 \% \\
\mathrm{NLM}^{\mathrm{a}}\end{array}$ & $5.81^{\mathrm{b}} \pm 0.01$ & $4.32^{\mathrm{abc}} \pm 0.03$ & $2.39^{\mathrm{abc}} \pm 0.02$ \\
\hline $\begin{array}{l}\mathrm{T}_{6}-\text { Basal diet }+1.0 \% \\
\text { NLM }\end{array}$ & $5.07^{\mathrm{ab}} \pm 0.02$ & $3.79^{\mathrm{abc}} \pm 0.03$ & $1.92^{\mathrm{ab}} \pm 0.02$ \\
\hline $\begin{array}{l}\mathrm{T}_{7}-\text { Basal diet } 0.025 \% \\
\text { chitosan }+0.5 \% \text { NLM }\end{array}$ & $4.15^{\mathrm{a}} \pm 0.02$ & $3.58^{\mathrm{ab}} \pm 0.02$ & $1.65^{\mathrm{a}} \pm 0.03$ \\
\hline $\begin{array}{l}\mathrm{T}_{8}-\text { Basal diet }+0.05 \% \\
\text { chitosan }+1.0 \% \text { NLM }\end{array}$ & $4.12^{\mathrm{a}} \pm 0.04$ & $3.28^{\mathrm{a}} \pm 0.04$ & $1.39^{\mathrm{a}} \pm 0.02$ \\
\hline
\end{tabular}

Means within the same column bearing different superscripts differ significantly $(p<0.05)$

The results of the microbial count is in agreement those of Menconi et al., (2014) in broiler chickens and Liu et al., (2010) in Landrace pigs for chitosan supplementation and Bonsu et al., (2012) in broiler chickens for neem supplementation.

The reduction in the mean total intestinal bacterial count in the chitosan supplemented groups of broiler chickens could be due to the fact that the chitosan acts as an effective antimicrobial agent. Two main mechanisms have been suggested as the cause of the inhibition of microbial cells by chitosan. One mechanism is that the polycationic nature of chitosan interferes with bacterial metabolism by electrostatic stacking at the cell surface of bacteria (Chung et al., 2004; Je and Kim, 2006). The other is blocking of transcription of RNA from DNA by adsorption of penetrated chitosan to DNA molecules. Immune response by the cooperation of cytokines to activate the non-specific immune system of animals (Lambrecht et al., 1999).
During this process, the activated macrophages would release cytokines such as TNF-a, IL-1B, IL-6 and IFN- $\gamma$ to inhibit the growth of a wide variety of microorganisms with the help of nitric oxide (NO) cytolytic function and inducible nitric oxide synthase (iNOS) (Je and Kim, 2006; Dou et al., 2007).

The expression of iNOS is essential for the killing of microbes and functions of NO in the regulation of immune responses (Xing and Schat, 2000). Chitosan enhanced iNOS mRNA expression in duodenum, jejunum, and ileum and thus improved the gut immune system and gut health ( $\mathrm{Li}$ et al., 2009). Similarly, the neem had antimicrobial effect against E. coli and Staphylococcus aureas (Sairam, 1997) and chitosan and neem combination had better bactericidal effect due to their synergistic effect on the microbes (Rajendran et al., 2012).

Hence, it could be concluded that supplementing the broiler chickens with 
chitosan and NLM in combination at both the levels caused a significant reduction in the total gut bacterial total Clostridial counts. The total Coliform count was significantly reduced in the group supplemented with 0.05 per cent chitosan and 1.0 per cent NLM as compared with other groups.

\section{References}

BIS, 1992. Nutrient requirements for poultry. Bureau of Indian Standards, I.S.13574.

Bonsu, F.R.K., Kagya-Agyemang, J.K., Kwenin, W.K.J. and Zanu, H.K. 2012. Medicinal response of broiler chickens to diets containing neem (Azadirachta indica) leaf meal, haematology and meat sensory analysis. World App. Sci. J., 19: 800-805.

Brahmachari, G. 2004. Neem - an omnipotent plant, Chem. Biochem. 5: 408-421.

Chung, C.Y., Su, Y.P., Chen, C.C., Jia, G., Wang, H.L. Wu, J.C. and Lin, G.J. 2004. Relationship between antibacterial activity of chitosan and surface characteristics of cell wall. Acta Pharmacol. Sin, 25: 932-936.

Dou, J.L., Tan, C.Y., Du, Y.G., Bai, X.F., Wang, K.Y. and Ma, X.J. 2007. Effects of chito oligosaccharides on rabbit neutrophils in vitro. Carbohydr. Polym, 69: 209-213.

El Hadrami, A., Adam L.R., El Hadrami I. And Daayf F. 2010. Chitosan in plant protection. Mar Drug, 8:968-987.

Friedman, M. and Juneja, V. K. 2010. Review of antimicrobial and antioxidative activities of chitosans in food. J Food Prot 73: 1737-1761.

Je, Y.J. and Kim, S.K. 2006. Chitosan derivatives killed bacteria by disrupting the outer and inner membrane. J. Agric. Food Chem., 54: 6629-6633.

Kong, M., Chen, X. G., Xing, K. and Park, H. J. 2010. Antimicrobial properties of chitosan and mode of action: A state of the art review. Int J Food Microbiol, 44:51-63.

Koul, A., Ghara, A.R. and Gangar, S.C. 2006. Chemomodulatory effects of Azadirachta indica on the hepatic status of skin tumor bearing mice. Phytother. Res., 20: 169-177.

Lambrecht, B., Gonze, M., Morales, D., Meulemans, G. and Vandenberg, T.P. 1999. Comparison of biological activities of natural and recombinant chicken interferon-gamma. Vet. Immunol. Immunopathol, 70: 257-267.

Liu, P., Piao, X.S., Thacker, P.A., Zeng, Z.K., Li, P.F., Wang, D. and Kim, S.W. 2010. Chito-oligosaccharide reduces diarrhea incidence and attenuates the immune response in weaned pigs B1 with Escherichia coli K88. J. Anim. Sci., 88: 3871-3879.

Menconi, G., Tellez, I., Faulkner, O.B., Wen, Z., Lei, Y., Xu, S., Xiao-Ting, Z. and Zi-Rong, X. 2014. Chitosan nanoparticles act as an adjuvant to promote both Th1 and Th2 immune responses induced by ovalbumin in mice. Drugs, 9: 1038-1055.

No, H. K., Park, N. Y., Lee, S. H. and Meyers, S. P. 2002. Antibacterial activity of chitosans and chitosan oligomers with different molecular weights. Int J Food Microbiol, 74:6572.

Petrovich, I., Grigor'iants, L.A., Gurin, A. N.and Gurin, N. A. 2008. Chitosan: Structure, properties, use in medicine and stomatology. Stomatologiia (Mosk) 87:72-77.

Rabea, E. I., Badawy, M. E. T., Stevens, C. V., Smagghe, G. and Steurbaut, W. 2003. Chitosan as antimicrobial agent: Applications and mode of action. Bio macro molecules, 4:1457-1465.

Rajendran, R., Radhai, R., Balakumar, C., Mohammad Ahmaed, H.A., 
Vigneshwaran, C. and Veideki, K. 2012. Synthesis and characterization of neem chitosan nanocomposites for development of antimicrobial cotton textiles. J. Eng. Fiber Fabr, 7: 136-141.

Sairam, M., Sharma, S.K., Ilavazhagan, G., Kumar, D. and Selvamurthy, W. 1997. Immuno modulatory effects of NIM-76, a volatile fraction from neem oil. $J$. Ethnopharmacol., 55: 133-139.

Senel, S. and McClure, S. J. 2004. Potential applications of chitosan in veterinary medicine. Adv Drug Deliv Rev, 56:1467-1480.

Singla, A. K., Chawla, M. 2001. Chitosan: Some pharmaceutical and biological aspects-An update. J Pharm Pharmacol, 53: 1047-1067.

Smits, C. H. M., Veldman, A., Verkade, H. J. and Beynen, A. C. 1998. The inhibitory effect of carboxymethyl cellulose with high viscosity on lipid absorption in broiler chickens coincides with reduced bile salt concentration and raised microbial numbers in the small intestine. Poult. Sci., 77: 1534-1539.

Snedecor, G.M. and Cochran, W.C. 2007. Statistical Methods. $8^{\text {th }}$ edn. Oxford and IBH Publishing Company. Mumbai, India.

Tiwari, R., Verma, A, K., Chakraborty, S., Dhama, K. and Singh, S.V. 2014. Neem (Azadirachta indica) and its potential for safegurding health of animal and humans: A review. J. Bio. Sci., 14: 110123.

Vargas, M. and Gonzalez-Martinez, C. 2010. Recent patents on food applications of chitosan. Recent Pat Food Nutr Agric, 2:121-128.

Xing, Z. and Schat, K.A. 2000. Inhibitory effect of nitric oxide and interferongamma on the replication of Marek's disease virus. J. Virol., 74: 3605-3612.

\section{How to cite this article:}

Sirsat, S.D., P. Visha and Nanjappan, K. 2018. Effects of Dietary Chitosan and Neem Leaf Meal Supplementation on Intestinal Bacterial Count in Broiler Chickens. Int.J.Curr.Microbiol.App.Sci. 7(01): 3016-3022. doi: https://doi.org/10.20546/ijcmas.2018.701.358 